\title{
Bokmelding
}

\section{Linjer i profesjonsveiledningen gjennom 50 år}

\author{
Carl Christian Bachke ${ }^{1 *}$ \\ ${ }^{1}$ Fakultet for helse- og idrettsvitenskap, Universitetet i Agder \\ * Kontakt: carl.c.bachke@uia.no \\ Levende tradisjoner i profesjonsveiledning \\ Kaare Skagen. Kolofon forlag, 2020. 220 sider.
}

Da jeg som ansvarlig lærer gjennomførte mitt første ti-vekttalls-kurs i veiledningspedagogikk for helseog sosialarbeidere, kalenderåret 1994, organiserte jeg en seminaruke hvor erfarne veiledere fra disse fire profesjonene hadde en dag (fem timer) hver til å presentere hovedtrekk ved deres student/kollegaveiledning: Sykepleie, sosialarbeid, læreryrke og psykologfaglig arbeid. Den femte dagen ble avsatt til en paneldebatt hvor studentene stilte spørsmål til foredragsholderne. Oppsummert gav denne ukens undervisning studentene en gryende innsikt i noen profesjoners veiledningstradisjoner, og glimt av likheter og forskjeller. Dessverre hadde vi ikke den gangen noen pensumbok som kunne supplere ukens inntrykk gjennom å gi oversikter, sammenligninger og tydeliggjøre bakenforliggende idegrunnlag. Selv var jeg for fersk i faget til å gi studentene dette. Nå mer enn 25 år senere foreligger en slik bok, skrevet av en nestor i norsk veiledningspedagogikk, Kaare Skagen. I mine øyne absolutt på høy tid.

\section{Kilder og litteraturstudium}

Skagen har åpent beskrevet hvilke kilder boken bygger på: Akademisk veiledningsfaglig litteratur, publisert på disse norske forlagene (antall i parentes): Fagbokforlaget (17+3); Cappelen Damm (11+3); Gyldendal Akademisk (25+3) og Universitetsforlaget (2+1). Dessuten ble åtte titler funnet på andre måter. Totalt 72 publikasjoner, utgitt innen medio juli 2018 (ikke 73 som Skagen sier, for Gjems (1995) forekomme to steder).

$\AA ̊$ velge fagbøker som base for et slags litteraturstudium oppfatter jeg som originalt - i alle fall for veiledningsfeltet. Dessuten å analysere en så stor bokheim er krevende. Både volumet og tidsspennet for utgivelsene (ca. 1970-2018) borger for at kildenes validitet er solid. Imidlertid savner jeg at forfatteren hadde gjort mer rede for hvordan bøkene er lest, og hva som har styrt utvalget av synspunkter og perspektiver som har fått gjennomslag i den publiserte teksten.

\section{Valg og sekvensering av innhold}

Boken har ti kapitler. Kap.1 formidle et grunnriss av det $\varnothing$ vrige innholdet, inklusive redegjørelser for begrepene tradisjon og profesjonsveiledning. Kap.2-9 presenterer disse tradisjonene (kapittelnummer og yrkestilknytning i parentes):

- Profesjonsveiledning basert på humanistisk psykologi (2, lærer) - særlig Bues veiledningspedagogikk presenteres

- Nytt kunnskapsregime i profesjonsveiledning (3, lærer) - handler mest om Handal og Lauvås sin veiledningstilnærming

Published: 14.05.2021 
- Profesjonsveiledning på didaktisk grunnlag (4, lærer) - mye fokus på Bjørndal og Liebergs didaktiske relasjonsmodell, samt Grendstads konfluente pedagogikk

- Veiledning basert på kommunikasjons- og systemteori (5, sykepleier, sosialarbeider, lærer) Bateson er guruen, og norske formidlere er bl.a. Gjems, Linge, Jensen og Ulleberg

- Fra ekspertveiledning til myk coaching (6, idrett, PPT) - Fra Freud til Rogers og Gallwey, og norske fortolkere som Kvalsund, Gjerde, Johannessen, Kokkersvold \& Vedeler

- Profesjonsveiledning i sosial- og helsefag (7, sosialarbeidere og sykepleiere) - her finner man navn som Killén, Teslo, Bang, Vråle, Bjerknes \& Christiansen, Tveiten, samt Ulvestad \& Kärki

- Profesjonsveiledning og mentoring av nyansatte barnehage- og skolelærer (8, lærer) - spalteplass gis til veilederskribenter som Søndenå \& Sundli, Eik, Lejonberg \& Føinum

- Sosiokulturell veiledningstradisjon (9, ikke yrkesspesifisert) - guruene er Vygotsky og Bakhtin, og norske lanserer er bl.a. Dysthe, Skagen og Worum \& Bjørndal

For hvert kapitel har Skagen en oppsummerende tekst og en figur. Når det gjelder figurene, savner jeg samlet presentasjon av disse som innsteg til det siste kapitlet. Mulig det ville bli noe overlesset, men det kunne ha gitt leseren mer forståelse av hvorfor Skagen har valgt ut de ti punktene i sluttkapitlet «Pedagogisk realisme i profesjonsveiledning» (10, uavhengig av yrker). Uansett hjelper dette kapitlet til å gi leseren et oversiktsbilde av dagens status for profesjonspreget veiledningspedagogikk.

Kapitlene 2-9 følger en slags historisk sekvensering. Jeg skriver «en slags» fordi forfatteren har ikke fasenavnsatt eller periodisert epokene. I stedet har han vært opptatt av å få frem masterideer som ligger til grunn for de ulike tradisjonene. Ved det har Skagen poengtert at det nye bærer i seg mye av det gamle. For lesere som føler seg oversvømt med nyheter på sitt fagområde, kan det være godt å se at det også fins stabilisatorer.

\section{Noen andre vurderinger}

Av måten jeg beskrev kapitlenes yrkesbasis, ser man ikke overraskende at lærer dominerer som arnested. Imidlertid savner jeg kapitler om veiledning fra noen andre yrker som har lang fartstid på området: Håndverk- og terapi-yrker. Disse kan sies å være egne tradisjoner. Særlig psykologene har vært engasjert av det med ikke lite forskning, se Skjerve, Reichelt, Rønnestad.

Kildevalget kunne vært utvidet til å omfatte doktorgrader og vitenskapelige artikler om veiledning. F.eks. er ikke NORDVEI nevnt. Klart at det hadde vært interessant med tanke på å ettersjekke forfatterens beskrivelser. Trolig hadde det sprengt rammene for boken. Så det kan være en oppgave senere hen. Man kunne da også supplert med analyser av yrkesgruppers veiledningsmanualer.

Man kan spørre seg om tradisjonsbegrepet er for kortsiktig: Hvor mange år må noe være i sving før det blir en tradisjon? Gunnar Handal sa i 2000 at H/R neppe kunne anerkjennes som en tradisjon 17 år etter lanseringen av «På egne vilkår».

Skagen skal ha stor honnør for å trekke opp de linjene han gjør. Sammenhenger blir tydeligere, og likhetstrekk mellom profesjonsveiledninger blir eksplisitte. For meg som har vært aktiv veileder i 40 år, og opplevd bølger av kunnskap og ferdighetsbeskrivelser skylle over meg, (jf. forsidebildet), har han synliggjort mange av veiledningens vedvarende understrømmer. Kort og godt jeg forstår etter å ha lest boken, bedre hva jeg har holdt på med. I tillegg har jeg hatt mange gjensynets gleder med lærere og fagbøker som har preget min veiledningspraksis. Dessuten har jeg fått en bekreftelse på at det med seminaruken var ingen dårlig ide da den på det tidspunktet anskueliggjorde levende veiledningstradisjoner.

Boken anbefales som pensum på veiledningsutdanningene. 